\title{
Ergonomical Evaluation Methods of Repeated Shocks and Vibrations on High Speed Ships (2nd Report)
}

\author{
Hiroshi KANDA*, Yoshio MURAYAMA*, \\ Masato TANAKA** and Kiyoshi SUZUKI**
}

高速艇における繰返し衝撃・振動の人間工学的評価法一II

神田、寛・村山義夫・田中正人・鈴木潔

抄録

本論文は，第一報で提案した評価方法で求められた，三つの型のテスト艇の結果を提供し検討している。評価 は乗心地指数, 振動感覚量, 脊柱の傷害にかかわる動力学的反応指数 (DR I) が使用された。これらの方法は, それぞれの高速艇の特性によって, また海上の波高, 対船波向, 船速の測定条件によって, それぞれ適確に人間 耐性からの評価を可能とする。注目すべさことは, 操舵手用防振椅子の上部は操舵手椅子下の休に比べて評価值 が特に大きいことである。防振椅子の効果について再検討すべきである。また，波高率が 5 また 6 以上ではD R I が春椎の変形にかかわるような大きさになることが多く, 将来D R I による繰返し衝撃, 振動の評価基準を 新しく提案する必要がある。

\begin{abstract}
This paper provides and discusses the results of three type test ships, obtained in accordance with the evaluation method proposed in the first report. The evaluation was made by the vibration ride quality index, vibration sensibility magnitude and dynamic response index(DRI)related to spinal injury. These methods permit the precise evaluation of the vibration effect from the standpoint of human tolerance according to the particulars of the high speed ships and on such measuring conditions as the wave height, the wave directions relative to the ship and the ship speed. A phenomenon worthy of attention is that the evaluation value on the vibration-isolating seat for the helmsman was remarkably large compared with those on floor under the helmsman's seat.From the above, the effect of the vibrationisolating seat should be re-examined. And the value of DRI tends to become so large as to cause the deformation of vertebral bones when the crest factor is larger than 5 and 6 , and consequently, new proposal would be necessary to settle the evaluation criterion for the repeated shocks and vibrations by means of DRI.
\end{abstract}

1. Introduction

Analyzing methods of acceleration waves of repeated shocks and vibrations as well as their evaluation methods were proposed in the first report(1) and proved their excellency for evaluation based on the human tolerance.

The present report provides and discusses the results of shipboard test of the high speed ships.

\section{Test methods}

The evaluation was made for the acceleration of shocks and vibrations in vertical direction which might affect the human bodies seriously. The acceleration data was stored in the data recorder to be

*Member: Maritime Labour Research Institute

**Member: Research Institute of Maritime Engineering 


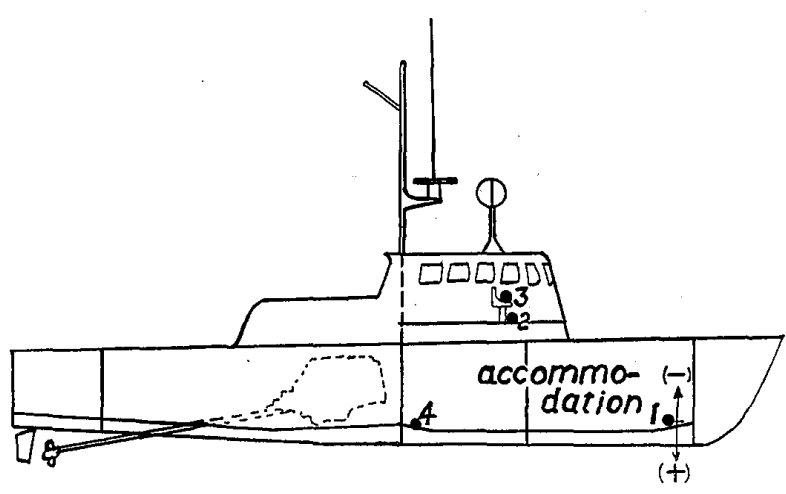

Fig. 1. Profile of a high speed ship and the measuring points of acceleration

Table 1 Test ships

\begin{tabular}{lllll}
\hline & $\begin{array}{l}\text { Length } \\
(\mathrm{m})\end{array}$ & $\begin{array}{l}\text { Gross } \\
\text { tonnage }\end{array}$ & $\begin{array}{l}\text { Full speed } \\
\text { (knot) }\end{array}$ & $\begin{array}{l}\text { Half speed } \\
\text { (knot) }\end{array}$ \\
\hline 21 m-type & 21 & 65 & 24 & 15 \\
\hline 30 m-type 30 & 88 & 30 & 24 \\
\hline 35 m-type 35 & 189 & 24 & 19 \\
\hline
\end{tabular}

analyzed in the laboratory.

The test ships are designated $\mathrm{A}, \mathrm{B}$ and $\mathrm{C}$ in Table 1, which are also named the $21 \mathrm{~m}$-type test ship, 30m-type test ship and 35m-type test ship respectively according to their length.

The measuring points are four in total as shown in Fig. 1. Three of them are on the floor at the fore part of accommodation (foreward portion of the ship), at the after part of accommodation (midship) and under the helmsman's seat in wheelhouse. The remaining one is on the helmsman's seat to examine the effect of a vibration-isolating seat.

In measuring vibrations where a resilient material such as the seat cushion exists between the human body and the vibrating substance, such a special care as inserting a thin metal sheet of appropriate shape should be taken.

Acceleration measurement on the seat cushion was made with an acceleration pickup fitted on an aluminum box (300 mm in length $\mathrm{x} 300 \mathrm{~mm}$ in width $\times 30 \mathrm{~mm}$ in height and weighs $1.3 \mathrm{~kg}$ ) as proposed by Miwa(2).

Measuring conditions on the sea were determined as follows:

Wave direction: Head sea, bow sea, beam sea, quarter sea and following sea

Ship speed: $\quad$ Full speed and half speed

Wave height: Several conditions

The evaluation on the results was made by the vibration ride quality index (VRQI), vibration level (VL), peak value of equivalent sensibility acceleration (ESA) and peak value of dynamic response index (DRI) obtained during analyzing period of 100 seconds of acceleration.

Since the evaluation methods were detailed in the first report, the present report outlines the criteria for evaluation as follows.

a. VRQI

VRQI is divided into two parts according to the frequency range: VRQI $\sim 1 \mathrm{~Hz}$ ) and $\operatorname{VRQI}(1 \sim 80 \mathrm{~Hz})$. $\operatorname{VRQI}(\sim 1 \mathrm{~Hz})$ is an evaluation index of the vibration in a frequency range below $1 \mathrm{~Hz}$ viewed from degree of difficulty in ordinary tasks or from motion sickness incidence caused by ship's oscillatory motion. VRQI $(1 \sim 80 \mathrm{~Hz})$ is an evaluation index of the vibration in a frequency range from 1 to $80 \mathrm{~Hz}$ on the basis of tolerable limit of spinal, viscerals and body.

The proposal sets the limit values for "tolerance limit" as 0.2 for an exposure less than one hour and 0.1 for a longer term.

In addition, the limit values for "severe" are 0.5 for an exposure less than one hour and 0.2 for a longer term.

b. VL

VL is used as a unit for exposure limit to vibrations to evaluate the degree of environmental pollution in Japan and is considered the most suitable vibration magnitude for the vibration sensibility rating. 
H. Kanda(3) states that the three judgment categories "somewhat", "considerably" and "very" representing severity of vibrations based on the human sensibility correspond to $83 \mathrm{~dB}, 89 \mathrm{~dB}$ and $95 \mathrm{~dB}$ respectively in the accommodation of large merchant ships. It is also reported that most of vibrations were below $80 \mathrm{~dB}$ in the accommodation of large merchant ships and claims were seldom raised by the crew.

c. Peak value of ESA

The peak value of ESA is the maximum value during a given period of the acceleration waves obtained by passing the weighting network for equivalent sensibility specified in ISO and is indispensable for the evaluation of shock sensibility.

During the shipboard test, the shock sensibility was observed appreciable at $0.8 \mathrm{~g}$ of ESA and fairly distinct at $1 \mathrm{~g}$ of ESA.

The present report pays attention to the range above $0.8 \mathrm{~g}$ for the evaluation of shock sensibility.

d. Peak value of DRI

The index concerns the spinal injury due to repeated shocks and vibrations.

Tentative limits for DRI was proposed(4)by G. R. Allen.

According to the results of X-ray examination of the crew's vertebra on high speed ships, the authors have found that the remarkable deformation of vertebral bones occured in a short term and tried to establish a tentative exposure limit for DRI to the repeated shocks and vibrations on the basis of this phenomenon, which is scheduled to be reported as the third report.

Judging from the survey results, the repeated shocks and vibrations greater than 0.5 of DRI seems to affect the deformation of vertebral bones.

In the present report, the repeated shocks and vibrations affecting the deformation of vertebral bones were considered greater than 0.5 of DRI and the evaluation was made by the peak value representing the maximum value during an analyzing period of 100 seconds.

3. Results and Consideration

3. 1 The $21 \mathrm{~m}$-type test ship A

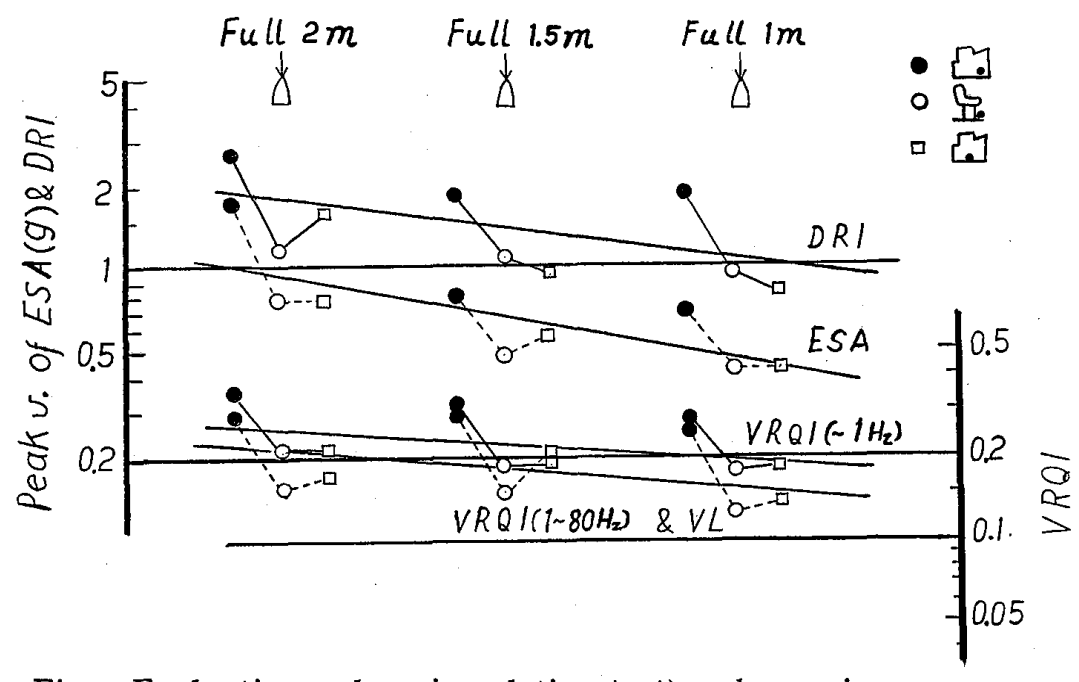

Fig. 2 Evaluation values in relation to the change in wave height at full speed in the head sea -21m-type test ship A-
Fig. 2 shows the evaluation values in relation to the change in wave height at full speed in the head sea. The right ordinate represents VRQI, and the left, the peak value of ESA and . DRI.

In a wave height of $2 \mathrm{~m}$, the peak value of DRI at the fore part of accommodation exceeds 2 and those at the wheelhouse and the after part of accommodation exceed 1 . The peak value of ESA is almost $2 \mathrm{~g}$ at the fore part of accommodation and $0.8 \mathrm{~g}$, a value to give slight shock feeling, at the wheelhouse and

the after part of accommodation. The values of $\operatorname{VRQI}(\sim 1 \mathrm{~Hz})$, an index for evaluation of oscillatory motion, exceed 0.2 , the value of "tolerable limit" for an exposure less than one hour at all measuring points, and the values of VRQI $(1 \sim 80 \mathrm{~Hz})$, an index for evaluation of vibration, are less than 0.2 , the "tolerance limit" value at the wheelhouse and the after part of accommodation. The test condition at a wave height of $2 \mathrm{~m}$ is the most severe condition for the test ship A and a long term operation was 
considered dangerous judging from the standpoints of both hull strength and crew's tolerance.

Fig. 2 indicates that each evaluation value reduces: when the wave height changes from $2 \mathrm{~m}$ to $1.5 \mathrm{~m}$ and further to $1 \mathrm{~m}$. At the wave heights of $1.5 \mathrm{~m}$ and $1 \mathrm{~m}$, each peak value of DRI is nearly 2 at the fore part of accommodation and almost 1 at the wheelhouse and the after part of accmmodation. The values of VRQI $(\sim 1 \mathrm{~Hz})$ and VRQI $(1 \sim 80 \mathrm{~Hz})$ at the fore part of accommodation exceed 0.2 , the"toler: ance limit" value for an exposure less than one hour, and those at the wheelhouse and the after part of accommodation either slightly exceed the limit value 0.2 or exceed 0.1 , the "tolerance limit" value for a longer term.
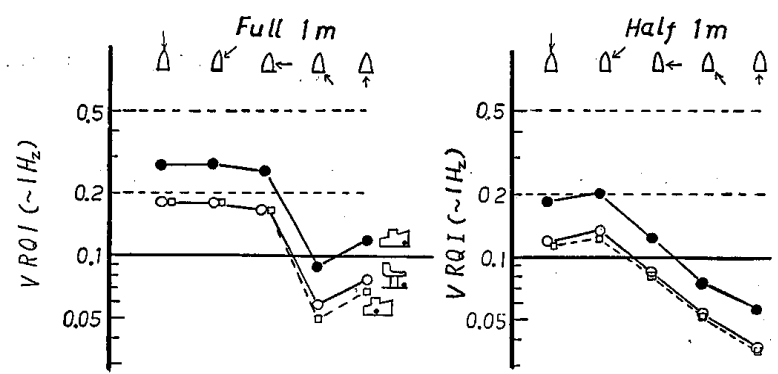

Fig. 3a Values of VRQI $(-1 \mathrm{~Hz})$ in relation to the change in wave direction with a wave height of $1 \mathrm{~m}$ at full or half speed

$-21 \mathrm{~m}$-type test ship A-
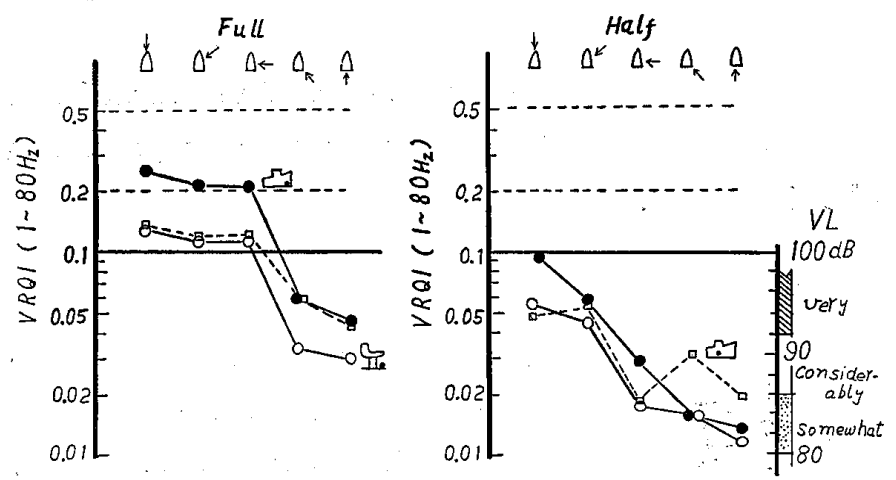

Fig. 3b Values of VRQI $(1-80 \mathrm{~Hz})$

$-21 \mathrm{~m}$-type test ship A-
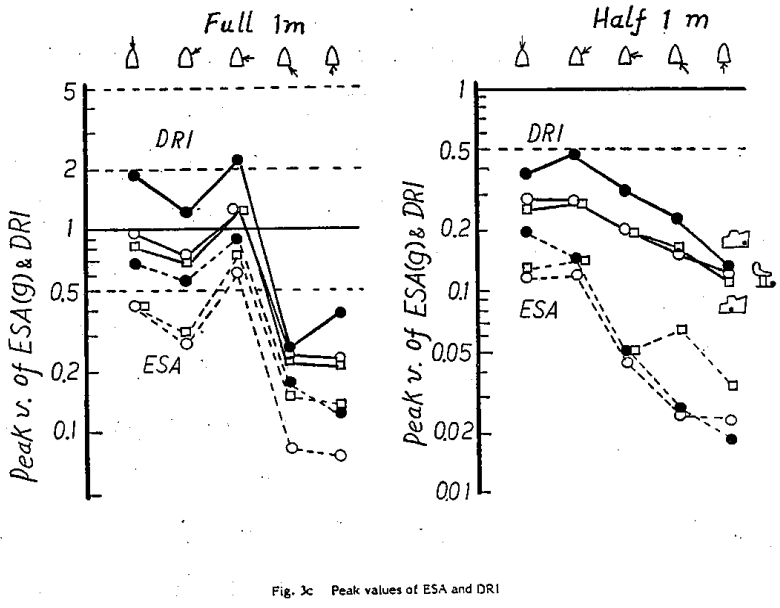

-2 Im-type test shipA.

Fig. 3c Peak values of ESA and DRI

$-21 \mathrm{~m}$-type test ship A-
Under the conditions as mentioned above, the crew in standing position in the wheelhouse were forced to hold the fixtures to prevent from staggering and, especially when the ship jumped up and down, to be serious to keep his posture by flexing his knees or by similar countermeasures. It was quite dangerous to move on foot into accommodation where the waves cannot be observed and the resultant shocks cannot be predicted.

Table 2 provides the peak frequencies of the vibrations in frequency range from 1 to $80 \mathrm{~Hz}$ and periods of the oscillatory motions for each test ship obtained from the power spectrum of acceleration waves passed through the weighting network of VRQI $(1 \sim 80 \mathrm{~Hz})$ and $\operatorname{VRQI}(\sim 1, \mathrm{~Hz})$. In the case of high speed ships the zone of vibration frequency is lower and the oscillating period is smaller than those in the case of conventional merchant ships. The oscillating period varies with the wave direction relative to the ship and takes its shortest value in the head sea as expected.

For the test ship A in the head sea, the peak values of the oscillating period and of the vibration were $1.3 \sim 2$ sec and $1.1 \sim 2.6$ $\mathrm{Hz}$ respectively, both of which have natures to make the crew's posture unstable. In addition, the repeated shocks caused by jumping up and falling onto water would fail the crew to keep his posture, thus being one of main factors to deteriorate the crew's working environment on high speed ships.

Figs. $3 \mathrm{a}, 3 \mathrm{~b}$ and $3 \mathrm{c}$ give the evaluation values in relation to the change in wave direction with a wave height of $1 \mathrm{~m}$ and at full or half speed. 
Table 2 Peak frequency of vibrations $(1-80 \mathrm{~Hz})$ and peak period of oscillatory motions

\begin{tabular}{|c|c|c|c|}
\hline & $\begin{array}{l}\text { 21m-type } \\
\text { test ship A }\end{array}$ & $\begin{array}{l}30 \mathrm{~m} \text {-type } \\
\text { test ship B }\end{array}$ & $\begin{array}{l}35 \mathrm{~m} \text {-type } \\
\text { test ship C }\end{array}$ \\
\hline P.F $(\mathrm{Hz})$ & $1.1-2.6$ & $1.1-3.2$ & $1.1-2.3$ \\
\hline \multirow[t]{5}{*}{ P.P(sec) } & $1.3-2.0$ & $1.3-2.0$ & 2.8 \\
\hline & 2.8 & $2.2-2.5$ & 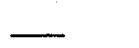 \\
\hline & 3.5 & $3.1-3.5$ & 3.2 \\
\hline & 3.5 & 3.5 & L \\
\hline & 3.3 & 4.4 & 3.8 \\
\hline
\end{tabular}

The values of $\operatorname{VRQI}(\sim 1 \mathrm{~Hz})$ at full speed, shown in Fig. 3a, exceed the reference value 0.2 at the fore part of accommodation and are about 0.18 at the wheelhouse and the after part of accommodation in the head sea, bow sea and beam sea. In the following sea, the value at the fore part of accommodation exceeds the reference value 0.1 . At half speed, these values at the fore part of accommodation in the head sea and bow sea are the reference value 0.2 or in the vicinity and those at the wheelhouse and the after part of accommodation exceed the reference value 0.1 . In the

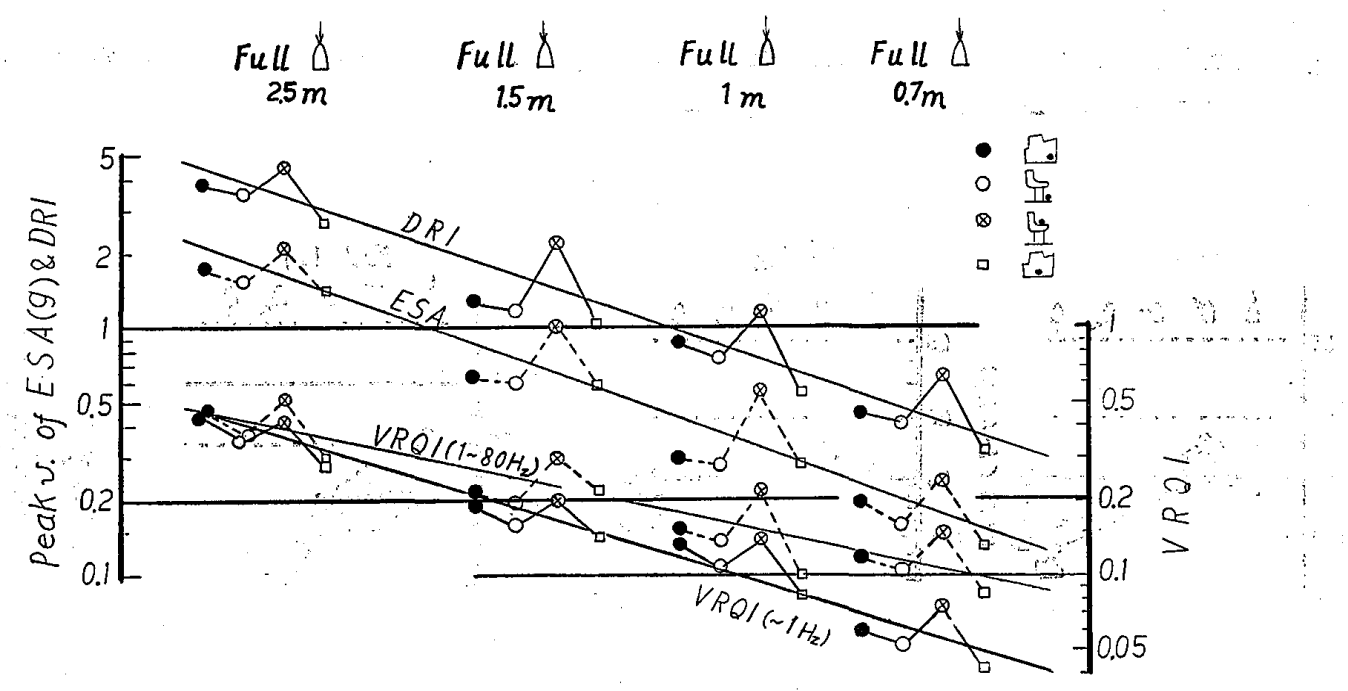

Fig. 4 Evaluation values in relation to the change in wave height at full speed in the head sea -30m-type test ship B-

beam sea, the value at the fore part of accommodation exceeds the reference value 0.1.

The values of VRQI $(1 \sim 80 \mathrm{~Hz})$ at full speed, shown in Fig. $3 \mathrm{~b}$, exceed the reference value 0.2 at the fore part of accommodation and exceed the reference value 0.1 at the wheelhouse and the after part of accommodation in the head sea, bow sea and beam sea.

At half speed, the values were below the reference value 0.1 in all wave directions, which indicate that the components of vibration significantly decrease compared with those of the oscillatory motion shown in Fig. 3a when the ship speed reduces to half. However, when the VL value represented by the graduation on the right ordinate is compared with the evaluation criteria(3) obtained forthe conventional merchant ships, it will be obvious that the vibration having the VRQI $(1 \sim 80 \mathrm{~Hz})$ values below the reference value 0.1 is of such a high level that cannot be experienced on the conventional merchant ships. From the abovementioned facts it could be understood that VL is an index to evaluate the reduced comfort level and VRQI $(1 \sim 80 \mathrm{~Hz})$ is an index to evaluate the degree of difficulty of the work and safety maintenance.

The peak value of ESA at-full speed shown in Fig. $3 \mathrm{c}$ is $0.9 \mathrm{~g}$ at the fore part of accommodation in the beam sea. Those under the other measuring conditions, however, are less than $0.8 \mathrm{~g}$. Those at half 


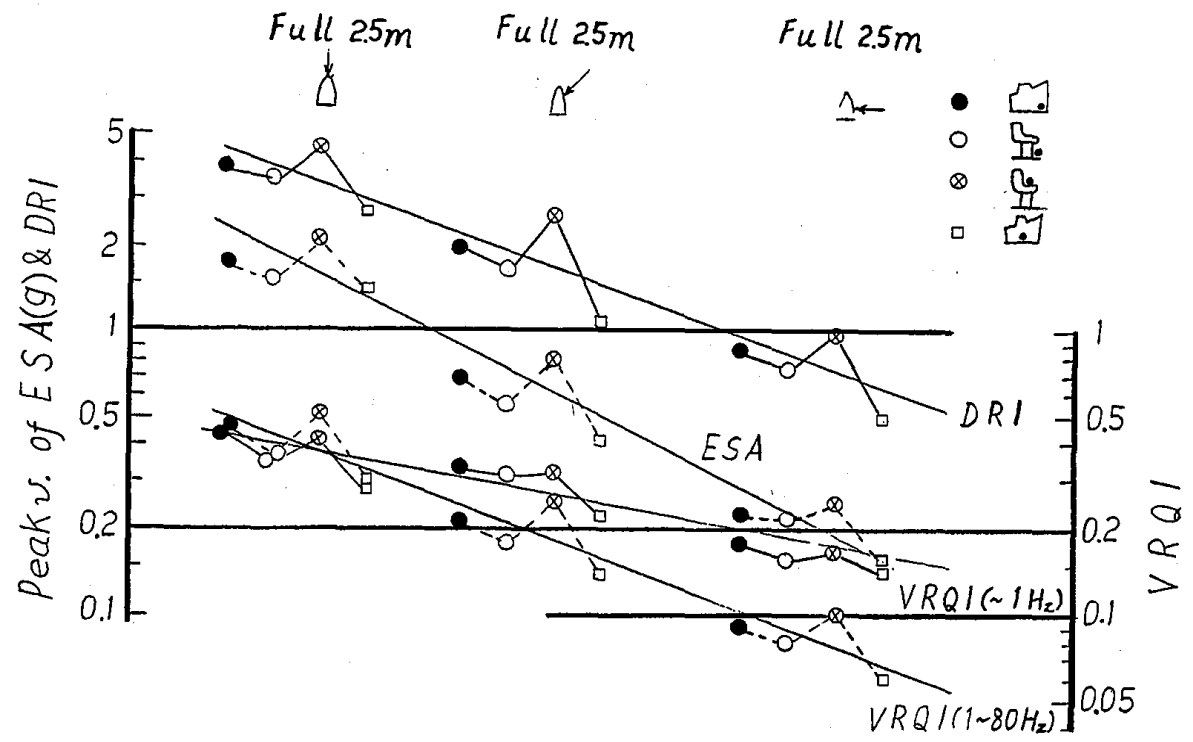

Fig. 5 Evaluation values in relation to the change in wave direction with a wave height of $2.5 \mathrm{~m}$ at full speed -30m-type test ship B-

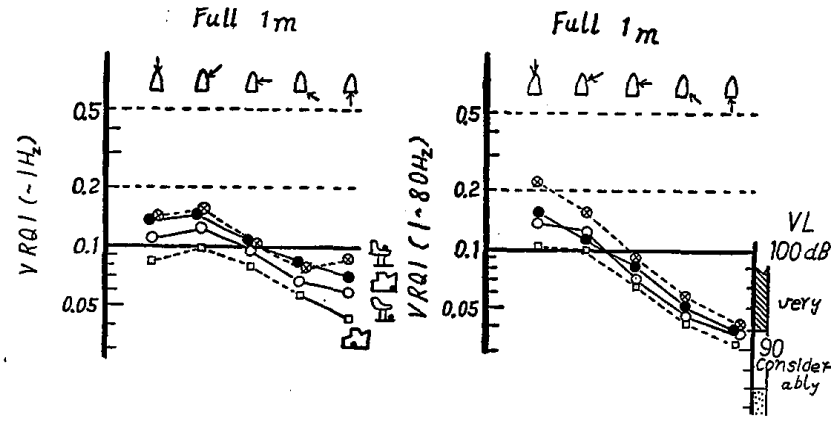

Fig. 6a Values of VRQI in relation to the change in wave direction with a wave height of $1 \mathrm{~m}$ at full speed-30m-type test ship B-
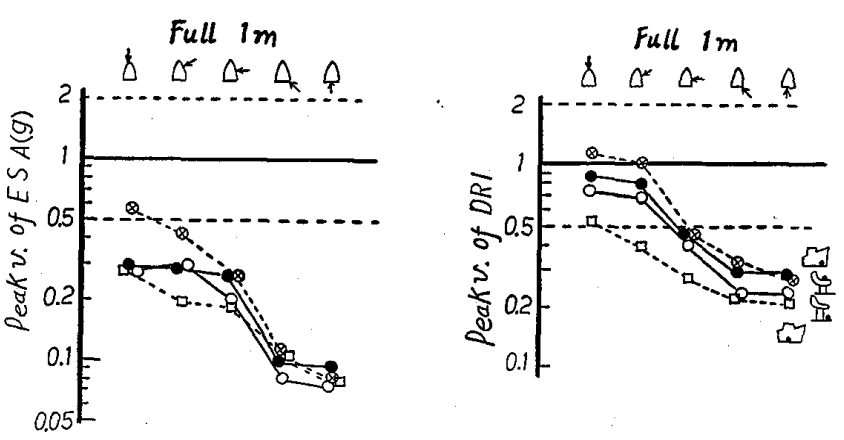

Fig. 6b Peak values of ESA and DRI -30m-type test ship B-

speed are small in any wave direction. Those peak values of DRI at full speed exceed 0.5 at the wheelhouse and the after part of accommodation and that at the fore part of accommodation exceeds 1.0 in the head sea and bow sea. In the beam sea, the values at the wheelhouse and the after part of accommodation exceed 1.0 and that at the fore part of accommodation exceeds 2.0 . At half speed, the peak values of DRI decrease remarkabiy to 0.5 or below.

Fig. 3 indicates that the shock and vibration environment is considerably improved by reducing the ship speed from full to half and also by changing the wave directions from the head sea to following sea. In the quarter and following sea, shift of the position into the accommodation on foot was possible subject to careful movement.

\subsection{The 30m-type test ship B}

Fig. 4 shows the evaluation values in relation to the change in wave height at full speed in the head sea. The test ship $B$ is the fastest among three ships running at 30 knots.

The test condition at a $2.5 \mathrm{~m}$ wave height was the most severe condition among the tests and a long-term operation under this condition was considered quite dangerous judging from the standpoints of both hull strength and crew's tolerance. The values of VRQI $(\sim 1 \mathrm{~Hz})$ and VRQI $(1 \sim 80 \mathrm{~Hz})$ were 

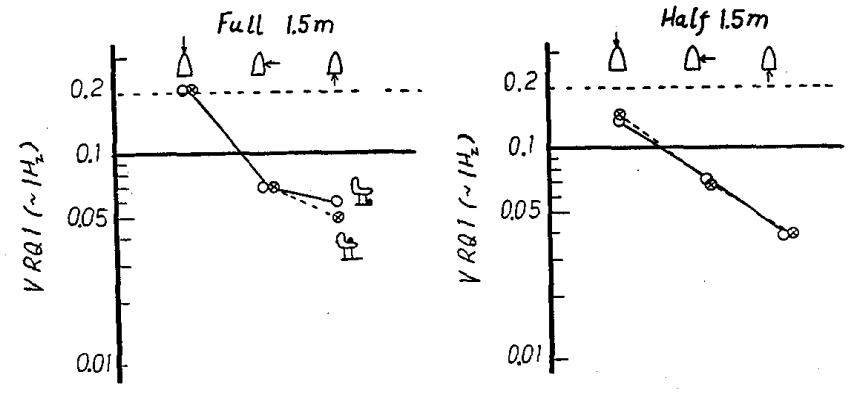

Fig. 7a Values of VRQI $(-1 \mathrm{~Hz})$ in relation to the change in wave direction with a wave height of $1.5 \mathrm{~m}$ at full or half speed -35m-type test ship C-
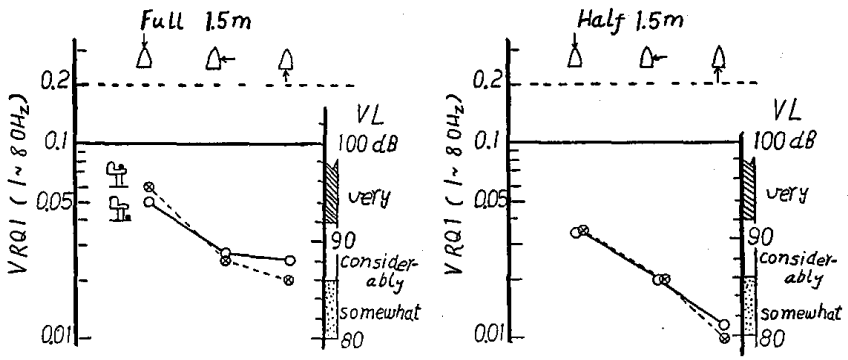

Fig. 7b Values of VRQI $(1-80 \mathrm{~Hz})$

$-35 \mathrm{~m}$-type test ship C-
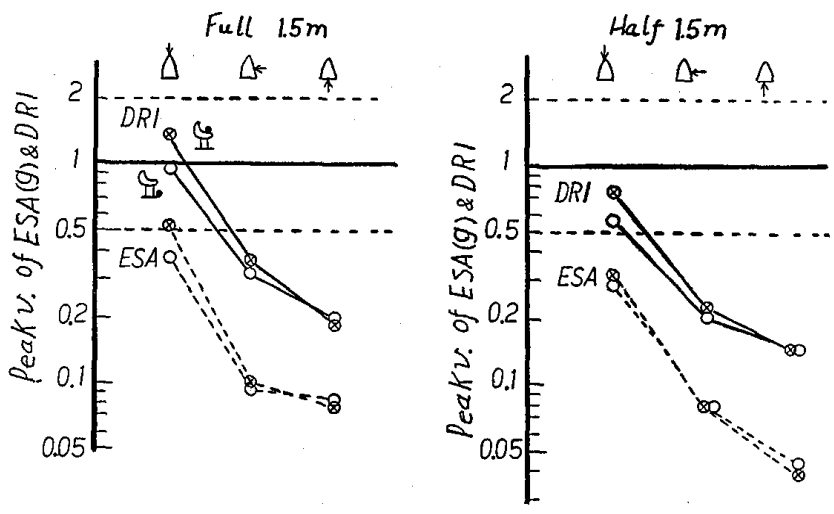

Fig. 7c Peak values of ESA and DRI $-35 \mathrm{~m}$-type test ship C-

A, the values of VRQI $(1 \sim 80 \mathrm{~Hz})$ are larger than those of VRQI $(\sim 1 \mathrm{~Hz})$ in the head sea. This seems to be caused by the fact that the test ship B is faster than the test ship A. Shift of the position into the accommodation on foot was possible only at the wave height of $0.7 \mathrm{~m}$ subject to careful movement.

Fig. 5 shows the decreasing state of evaluation values corresponding to the change of wave direction at full speed and a wave height of $2.5 \mathrm{~m}$. The peak vaiue of DRI exceeds 0.5 even in the beam sea where the evaluation value is the smallest, and the value of $V R Q I(\sim 1 \mathrm{~Hz})$ exceeds the reference value 0.1 . On the whole, decreasing rate of VRQI $(1 \sim 80 \mathrm{~Hz})$ value for vibrations is greater than that of VRQI $(\sim 1 \mathrm{~Hz})$ value for oscillatory motions. This indicates that the wave direction affects largely the magnitude of vibration.

Figs. $6 \mathrm{a}$ and $6 \mathrm{~b}$ show the evaluation values in relation to the change in wave direction with a wave well over the limit value 0.2 at an exposure less than one hour indicating a quite severe condition. The peak value of ESA was $1.6 \mathrm{~g}$ on the wheelhouse floor. In this case, a feeling of being levitated in the air was experienced just before the ship fell down and shock of considarable large magnitude was felt at jumping onto water and the DRI value on the wheelhouse floor was 3.5. Although the shock feeling was not such a serious extent that breakage of the vertebral bones would be resulted, the working environment represented by these test results is very severe to the crew.

A phenomenon worthy of attention is that the for the helmsman was remarkably large compared with those on floor under the helmsman's seat, and this tendency was same at various wave heights. From the above, the effect of the vibration-isolating seat should be re-examined.

Fig. 4 shows also that the evaluation value decreases when the wave height changes stepwise from $2.5 \mathrm{~m}$ to $0.7 \mathrm{~m}$. The peak values of DRI exceed 1 at a wave height of $1.5 \mathrm{~m}$ and exceed 0.5 at a wave height of $1 \mathrm{~m}$ at all measuring positions and exceed 0.5 at a wave height of $0.7 \mathrm{~m}$ on the vibration-isolating seat. The values of VRQI exceed significantly reference value 0.2 at wave height of $2.5 \mathrm{~m}$, and are approximately the reference value 0.2 at a wave height of $1.5 \mathrm{~m}$ and between 0.1 and 0.2 at a wave height of $1 \mathrm{~m}$. At a wave height of $0.7 \mathrm{~m}$ the values of VRQI $(1 \sim 80 \mathrm{~Hz})$ exceed 0.1 except the after part of accommodation and the values of VRQI $(\sim 1 \mathrm{~Hz})$ in all cases are less than the reference value 0.1 . In contrast to the case of the test ship 


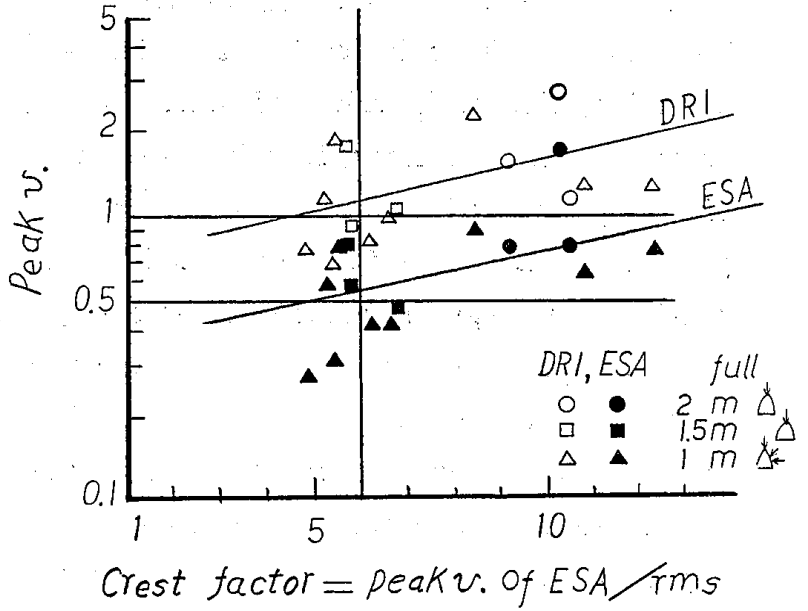

Fig. 8a Crest factor, relationship of the peak value between ESA and DRI

$-21 \mathrm{~m}$-type test ship A -

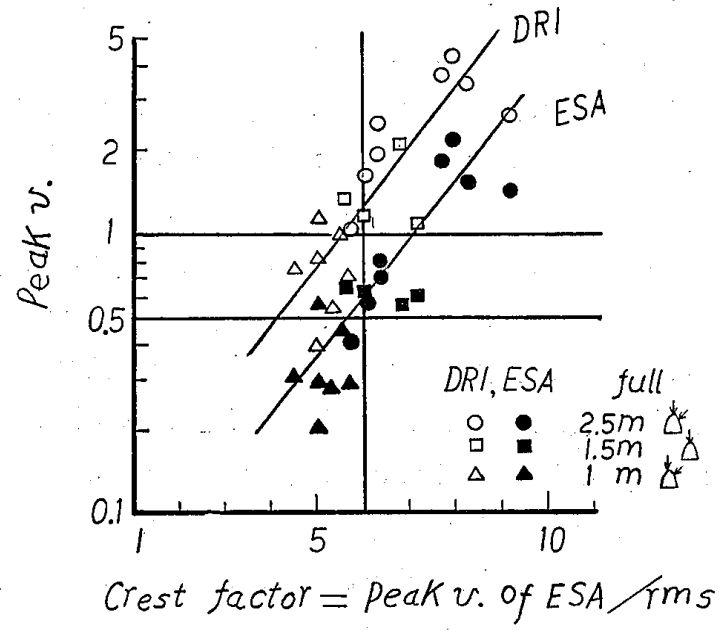

Fig. 8b -30m-type test ship B - height of $1 \mathrm{~m}$ at full speed. The values of VRQI $(\sim 1 \mathrm{~Hz})$ at the after part of accommodation, shown in Fig. 6a, are less than the reference value 0.1 in all wave directions, but those at other three measuring points exceed the reference value 0.1 in the head sea and bow sea; and are approximatly the reference value 0.1 at the beam sea. The values $(1 \sim 80 \mathrm{~Hz})$ exceed 0.1 at all measuring points in the head sea and bow sea.

The peak values of ESA shown in Fig. $6 \mathrm{~b}$ are small and the peak values of DRI exceed 0.5 in the head sea and bow sea except at the after part of accommodation in the bow sea.

Shift of the position into the accommodation on foot was possible in the quarter sea and following sea in these test records subject -to careful movement.

3.3 The 35m-type test ship C

Figs. $7 \mathrm{a}, 7 \mathrm{~b}$ and $7 \mathrm{c}$ give the evaluation values in relation to the change in wave direction with a wave height of $1.5 \mathrm{~m}$ at full or half speed.

Since the test ship $C$ is the largest one among the test ships, weighing 160 tons, strong landing shocks to the hull which are caused by jamping at the wave crest and falling onto water at the trough are hard to occur. Measurement was taken only, at two positions, on the wheelhouse floor and on the vibration-isolating seat.

In the head sea, the value of $\operatorname{VRQI}(\sim 1 \mathrm{~Hz})$

shown in Fig. 7a exceeds slightly the reference value 0.2 at full speed and exceeds the reference value 0.1 at half speed, which indicates the oscillatory motion is considerably large. In the beam sea and following sea the oscillatory motions become small both at full and half speed.

The values of VRQI $(1 \sim 80 \mathrm{~Hz})$ shown in Fig. $7 \mathrm{~b}$ are fairly small even in the head sea compared with those for the test ships $A$ and $B$.

The peak value of ESA in Fig.7c is small and the shocks are hardly felt. The peak value of DRI on the vibration-isolating seat exceeds the reference value 1 and that on the wheelhouse floor is nearly 1 in the head sea at full speed. They both exceed 0.5 in the head sea at half speed.

Also, in beam sea and following sea in these test records, shift of the position into the accommodation on foot was possible both at full speed and at half speed subject to careful movement.

\subsection{Examination of the crest factor}

The crest factor, being the ratio of a peak value to rms value, is attracting attention within ISO members as described in the first report. In the Appendix of ISO 2631(5) concerning the evaluation of vibration it is specified that the standard is applicable to the crest factors not more than 6 and is proposed that the acceleration waves should be weighted by passing the weighting network for equivalent sensibility and that the exposure period should not be less than one minute. Therefore, the 
relationship of the crest factor proposed by ISO with the peak value of ESA as well as with the peak value of $D R I$ are examined on the basis of the test results.

Figs. $8 \mathrm{a}$ and $8 \mathrm{~b}$ show the abovementioned relationship on the basis of the results measured during an analysis period of 100 seconds on the $21 \mathrm{~m}$-type test ship A and $30 \mathrm{~m}$-type test ship B.

The abscissae of these figures represent the crest factor, or the ratio of the peak value of ESA proposed by the present study to the rms value. The ordinate represents the peak value of ESA and DRI. The figure shows the case of measuring conditions with larger crest factors and indicates that the peak values of ESA and DRI have a tendency to become large with increase of the crestifactor.

The difference between the peak values of DRI and ESA is caused by the difference of frequency ranges of vibrations, which are from 0.1 to $80 \mathrm{~Hz}$ for DRI and from 1 to $80 \mathrm{~Hz}$ for ESA. Namely, the cause of difference is that DRI is evaluated for the vibrations including those below $1 \mathrm{~Hz}$, so called the component for oscillatory motion.

These facts prove that, in the case of high speed ships, the value of DRI tends to become so large as to cause the deformation of vertebral bones when the crest factor is larger than 5 or 6 , and, consequently, new proposal would be necessary to settle the evaluation criterion for the repeated shocks and vibrations by means of DRI.

4. Conclusion

The present report shows the test results on three high speed ships, length of which are $21 \mathrm{~m}, 30 \mathrm{~m}$ and $35 \mathrm{~m}$, obtained in accordance with the evaluation method proposed in the first report.

The evaluation was made by the value of VRQI, the value of VL, the peak value of ESA and the peak value of DRI obtained during analyzing period of 100 seconds for acceleration. These evaluation methods permit the precise evaluation of the vibration effect from the standpoint of human tolerance according to the particulars of the high speed ships and also on such measuring conditions as the wave height, the wave derections relative to the ship and the ship speed.

Further problem to be clarified is the relationship of the repeated shocks and vibrations with frequent occurences of crew's low back pains. In particular, it is important to make clear how the DRI related to spinal injury and its repeated times relating to the deformation of the vertebral bones as well as frequent occurences of low back pains.

\section{Reference}

(1) Kanda, H. et al.; Ergonomical Methods of Evaluating Repeated Shocks and Vibrations on High Speed Ships(1st Report), J.Ins. of Navigation, Vol.63, 1-10, 1980.

(2) Miwa, T.et al.; Evaluation Methods for Vibration Effect. Part 10. Measurement of Vibration Attenuation Effect of Cushions, Ind. Health, Vol.9( 3), 81-98, 1971.

(3) Kanda, H. ; Studies on the Evaluation of Human Sensibility of Ship Vibration, J. Ins. of Navigation, Vol. 51, 77-83, 1972. (in Japanese)

(4) Allen.G. R. ; Progress on a Specification for Human Tolerance of Repeated Shocks, ISO/TC108/ $\mathrm{SC} 4, \mathrm{~N} 47$, Aug. 1976.

(5) SC4-Secretariat (DIN); Amendments to ISO 2631., ISO/TC108/SC4, N66, Sep. 1978. 